\title{
PROJECT BASED LEARNING: PENGARUHNYA TERHADAP KETERAMPILAN PROSES SAINS PESERTA DIDIK DI TANGGAMUS
}

\section{PROJECT BASED LEARNING: THE EFFECT ON STUDENT'S SCIENCE PROCESSES SKILLS IN TANGGAMUS}

\author{
Laila Okta Fitriyani ${ }^{1}$, Koderi ${ }^{2}$, Welly Anggraini ${ }^{3}$ \\ 1,2,3 Pendidikan Fisika, FTK UIN Raden Intan Lampung
}

Diterima: 13 September 2018, Disetujui: 30 Oktober, Dipublikasikan: 30 November 2018

\begin{abstract}
This study aims to find out is there a significant difference between the results of science process skills of students using project based learning with the results of science process skills of students using conventional learning. The research method used was Quasi Experiment. The instrument in this study used a science process skill test, in the form of observation sheets and multiple choice tests. Based on the results of research on the experimental class posttest data showing the results of the average percentage of science process skills, the experimental class received a percentage of $69.84 \%$ while the control class received an average value of $39.64 \%$. Then the t-test calculated from the posttest value shows that tcount $=10.17$ is greater $\mathrm{t}$ table $(0.05)=2$, so that tcount $>$ ttable. So it can be concluded that $\mathrm{H} 0$ is accepted, meaning that there are influences of science process skills of students using a project-based learning model. And based on the average value of science process skills measured by observation sheet is $79.37 \%$ with good categories, and the highest indicator in the experimental class is observing $85.41 \%$ and the lowest science process skills are hypotheses which is $75 \%$.
\end{abstract}

\begin{abstract}
Abstrak: Penelitian ini bertujuan untuk mengetahui adakah perbedaan yang signifikan antara hasil keterampilan proses sains peserta didik menggunakan pembelajaran berbasis proyek (project based learning) dengan hasil keterampilan proses sains peserta didik menggunakan pembelajaraan konvensional. Metode penelitian yang digunakan adalah Quasi Eksperimen. Instrumen dalam penelitian ini menggunakan tes keterampilan proses sains, berupa lembar observasi dan tes berupa pilihan ganda. Berdasarkan hasil penelitian data postest kelas eksperimen menunjukkan hasil nilai rata-rata persentasi keterampilan proses sains, kelas eksperimen mendapat persentasi sebesar 69,84\% sedangkan kelas kontrol mendapat nilai ratarata persentasi 39,64\%. Kemudian dihitung uji-t dari nilai postest menunjukkan bahwa $t_{\text {hitung }}=10,17$ lebih besar $t_{\text {tabel }(0,05)}=2$, sehingga $t_{\text {hitung }}>t_{\text {tabel }}$. Jadi dapat disimpulkan bahwa $\mathrm{H}_{0}$ diterima, artinya terdapat pengaruh keterampilan proses sains peserta didik dengan menggunakan model pembelajaran berbasis proyek. Dan berdasarkan nilai rata-rata keterampilan proses sains yang diukur dengan lembar obsevasi sebesar 79,37\% dengan kategori baik, serta indikator tertinggi pada kelas eksperimen yaitu mengamati sebesar $85,41 \%$ dan keterampilan proses sains yang terendah adalah hipotesis yaitu sebesar $75 \%$.
\end{abstract}

(C) 2018 Unit Riset dan Publikasi Ilmiah FTK UIN Raden Intan Lampung

Kata Kunci : Keterampilan Proses Sains, Project Based Learning, Model Pembelajaran. 


\section{PENDAHULUAN}

Pendidikan merupakan usaha sadar dan terencana untuk mewujudkan suasana belajar dan proses pembelajaran agar peserta didik secara aktif mengembangkan potensi dirinya untuk memiliki kekuatan spiritual, keagaman, pengendalian diri, kepribadian, kecerdasan, akhlak mulia, serta keterampilan yang diperlukan dirinya, masyarakat, Bangsa dan Negara. (Hasbullah, 2013).

Karena itu Islam sebagai agama rahmatan lil alamin sangat mewajibkan umatnya untuk selalu belajar. Seperti dalam Firman Allah Q.S Al-Anbiya ayat 7, yang artinya:

"Kami tidak mengutus rasul-rasul sebelum kamu (Muhammad), melainkan beberapa orang laki-laki yang kami beri wahyu kepada mereka, maka tanyakanlah olehmu kepada orang yang berilmu, jika kamu tidak mengetahui. (Q.S Al-Anbiya: 7)".

(Departemen Agama RI, 2010)

Pendidikan bertujuan untuk meningkatkan kualitas peserta didik. Kualitas pendidikan senantiasa menjadi perhatian utama dalam rangka memajukan generasi yang berkualitas. masalah utama yang dihadapi dunia pendidikan adalah menyangkut mutu pendidikan, terutama kualitas sains yang masih sangat rendah.

Sains biasanya berkaitan dengan cara mencari tahu dan memahami tentang alam secara sistematik, sehingga sains bukan hanya penguasaan tentang kumpulan pengetahuan yang berupa fakta-fakta, konsep-konsep, prinsip-prinsip saja tetapi juga merupakan suatu proses penemuan. Sains menekankan pada pemberian pengalaman secara langsung. Karena itu peserta didik perlu dibantu agar memiliki kecakapan dalam belajar yang meliputi kemampuan mengamati, berpikir, bekerja, bersikap ilmiah dan berkomunikasi. Dimana kecakapan tersebut merupakan bagian dari keterampilan proses sains (Komikesari, 2016).

Keterampilan proses sains adalah keseluruhan keterampilan ilmiah yang terarah yang dapat digunakan untuk menemukan suatu konsep, prinsip, atau teori untuk mengembangkan konsep yang telah ada sebelumnya, ataupun untuk melakukan penyangkalan terhadap suatu penemuan (Trianto, 2012). Selain itu Keterampilan proses sains memiliki kelebihn yaitu menjadikan siswa memiliki sifat aktif, kreatif serta terampil dalam berpikir dan dalam menemukan pengetahuan (Avianti \& Yonatha, 2015). Dengan memiliki sifat aktif, kreatif, serta terampil timbul interaksi di dalam proses pembelajaran yang membuat pembelajaran lebih bermakna (Yuberti, 2015). Maka dari itu, siswa dapat mengkonstruk pengetahuannya sendiri sesuai dengan sumber yang ada.

Keterampilan proses sains dibedakan menjadi 2 kelompok yaitu keterampilan dasar (basic skills) terdiri atas, mengamati, mengklasifikasikan, mengomunikasikan, mengukur, memprediksi dan menyimpulkan, dan keterampilan terintegrasi (integrated skills), yaitu Mengenali variabel, membuat tabel data, membuat grafik, menggambarkan hubungan antara variabel, mengumpulkan dan mengolah data, menganalisis penelitian, menyusun hipotesis, mendefinisikan variabel, merancang penelitian, dan bereksperimen (Dimayati \& Mujiono, 2006).

Proses pembelajaran sains khususnya fisika yang selama ini sering terjadi permasalahan. Permasalahan yang sering timbul selama ini di lapangan adalah cara mengajar guru yang sering menggunakan model konvensional, model konvensional cenderung menuntut Siswa untuk menghafal materi-materi yang diberikan oleh guru. Model pembelajaran tersebut belum dapat mendukung dalam proses pembelajaran yang berlangsung, yaitu 
dalam penjelasan materi maupun belum diadakan praktikum untuk materi yang seharusnya dipraktikumkan, hal ini menjadi masalah utama yang dihadapi dunia pendidikan menyangkut mutu Pendidikan (Kurnia \& Bahtiar, 2015) . Terutama pada kualitas keterampilan proses sains yang masih sangat rendah.

Rendahnya mutu pendidikan dikemukakan oleh The World Bank, mengatakan bahwa ada perbandingan akses dan kualitas tentang prestasi pendidikan di beberapa Negara. Output pendidikan di Indonesia hanya mencapai tingkat-tingkat berpikir rendah, yaitu pengetahuan, pemahaman, dan aplikasi, sedangkan untuk tingkat-tingkat berpikir yang tinggi, seperti analisis, evaluasi, dan kreativitas masih sangat rendah. Siswasiswa Indonesia hanya dapat menjawab soal-soal hafalan tetapi tidak dapat menjawab soal-soal yang memerlukan penalaran atau keterampilan proses.

Hal ini senada dengan hasil observasi penelitian di kelas VIII MTs. Swasta Matla'ul Anwar Gisting serta wawancara yang dilakukan dengan peserta didik dan ibu Yogi Fitriani, S.Pd selaku guru IPA di MTs. Swasta Matla'ul Anwar Gisting, menyatakan bahwa pembelajaran fisika yang telah dilaksanakan menunjukkan hanya sedikit peserta didik yang aktif pada proses pembelajaran, guru lebih menekankan pada pemahaman konsep, dimana guru hanya memberikan serangkaian latihan dan soal. Selain itu kegiatan praktikum atau kegiatan yang menunjukkan keterampilan proses sains peserta didik jarang dilaksanakan, hal ini dapat menyebabkan keterampilan proses sains peserta didik tidak berkembang. Akibatnya, peserta didik sulit dalam menerapkan konsep sains dalam kehidupan sehari-hari.

Berdasarkan hasil wawancara dan observasi kepada guru IPA serta peserta didik kelas VIII MTs. Swasta Matla'ul Anwar,maka perlu adanya upaya perbaikan dalam proses pembelajaran agar dapat meningkatkan keterampilan proses dalam pembelajaran IPA yaitu keterampilan mengamati, mengklasifikasikan, menerapkan konsep, memperdiksi, menafsirkan, merancang percobaan, dan menggunakan alat dan bahan. Satu diantara alternatif yang digunakan yaitu dengan menggunakan model pembelajaran berbasis proyek (project based learning).

Model pembelajaran berbasis proyek (project based learning) merupakan pemberian tugas kepada semua peserta didik untuk dikerjakan secara individual, peserta didik dituntut untuk mengamati, membaca dan meneliti (Aqib, 2014). Kemudian peserta didik diminta untuk membuat laporan dari tugas yang diberikannya dalam bentuk makalah.

Pembelajaran berbasis proyek (project based learning) memiliki keterkaitan erat dengan keterampilan proses sains peserta didik, karena dengan menggunakan model pembembelajaran berbasis proyek peserta didik dapat meningkatkan kreatifitas, keaktifan, kemampuan berfikir sehingga keterampilan proses sains peserta didik dapat berkembang.

Menurut hasil penelitian Tasiwa dalam penelitian tentang pengaruh model pembelajaran proyek terhadap keterampilan proses sains, bahwa kelas eksperimen yang menggunakan model pembelajaran berbasis proyek terhadap keterampilan proses sains lebih tinggi dari pada kelas kontrol yang tidak memakai model pembelajaran berbasis proyek.

Berdasarkan hasil penelitian yang telah diuraikan diatas bahwa, model pembelajaran berbasis proyek (project based learning) dapat meningkatkan keterampilan proses sains pada peserta didik. Dimana peserta didik dalam proses pembelajaran dengan model pembelajaran berbasis proyek (project based learning), peserta didik didorong untuk aktif, kreatif serta melalui model ini peserta didik dilatih untuk menyelesaikan masalah, mengambil keputusan, melakukan 
investigasi, dan membuat suatu karya untuk membantu mengatasi masalah sehingga dengan menerapkan pembelajaran berbasis proyek (project based learning) di kelas, pemahaman peserta didik akan konsep dan prinsip akan lebih mendalam serta menciptakan suasana pembelajaran yang menyenangkan dan mandiri.

Oleh karena itu, peneliti tertarik untuk melakukan penelitian dngan judul "Pengaruh Model Pembelajaran Berbasis Proyek (Project Based Learning)Terhadap Keterampilan Proses Sains Kelas VIII MTs. Swasta Matla'ul Anwar".

\section{LANDASAN TEORI}

Model pembelajaran berbasis proyek (project based learning) merupakan strategi belajar mengajar yang melibatkan peserta didik untuk mengerjakan sebuah proyek yang bermanfaat untuk menyelesaikan permasalahan masyarakat atau lingkungan (Sani, 2014).

Langkah-langkah pembelajaran dalam project based learning sebagaimana dikembangkan oleh The George Lucas Educational Foundation, terdiri dari:

a. Dimulai dengan pertanyaan yang esensial

Pertanyaan yang esensial diajukan untuk memancing pengetahuan, tanggapan, kritik, dan ide peserta didik mengenai tema proyek yang akan diangkat.

b. Perencanaan aturan pengerjaan proyek

Perencanaan berisi tentang aturan main, pemilihan aktivitas yang dapat mendukung dalam menjawab pertanyaan esensial, dengan cara mengintegrasikan berbagai subjek yang mungkin, serta mengetahui alat dan bahan yang dapat diakses untuk membuat penyelesaian proyek.

c. Membuat jadwal aktivitas
Pendidik dan peserta didik secara kolaboratif menyusun jadwal aktivitas dalam menyelesaikan proyek. Jadwal ini disusun untuk mengetahui berapa lama waktu yang akan dibutuhkan dalam pengajaraan proyek.

d. Memonitoring perkembangan proyek peserta didik

Memonitoring dilakukan dengan cara menfasilitasi peserta didik pada setiap proses.

e. Penilaian hasil kerja peserta didik

Penilaian dilakukan untuk membantu pendidik mengukur kecapaian standar, berperan dalam mengevaluasi kemajuan masing-masing peserta didik, memberi umpan balik tentang tingkat pemahaman yang sudah dicapai peserta didik, membantu pendidik dalam menyusun strategi pembelajaraan berikutnya.

f. Evaluasi pengalaman belajar peserta didik

Pada tahap ini peserta didik diminta untuk mengungkapkan perasaan dan pengalamaannya selama menyelesaikan proyek (Al-Tabany, 2014).

Keterampilan proses dapat diartikan sebagai wawasan atau panutan pengembangan keterampilanketerampilan intelektual, sosial, dan fisik yang bersumber dari kemampuankemampuan mendasar yang pada prinsipnya telah ada dalam diri peserta didik (Dimayati \& Mujiono, 2006)

Keterampilan proses sains terbagi menjadi keterampilan proses sains dasar dan keterampilan proses sains terpadu. Keterampilan proses sains dasar terdiri dari, mengamati atau mengobservasi, mengklasifikasi, berkomunikasi, mengukur, meramal dan menarik kesimpulan. Dan keterampilan proses sains terpadu terdiri dari, identifikasi variabel, penyusunan tabel data, penyusunan grafik, pemprosesan data, analisis investigasi, penyusunan hipotesis, 
penyusunan variabel-variabel secara operasional dan perancang investigasi (Widayanto, 2009).

\section{METODE PENELITIAN}

Pada penelitian ini digunakan metode Quasi Eksperiment Design. Desain penelitian yang digunakan dalam penelitian ini adalah nonequivalent control group desing, Desain penelitian dapat dilihat pada tabel 1 di bawah ini, sebagai berikut:

Tabel 1. Desain Penelitian

\begin{tabular}{|c|c|c|c|}
\hline $\begin{array}{c}\text { Kelas } \\
\text { Eksperimen }\end{array}$ & $\mathrm{O}_{1}$ & $\mathrm{X}$ & $\mathrm{O}_{2}$ \\
\hline $\begin{array}{c}\text { Kelas } \\
\text { Kontrol }\end{array}$ & $\mathrm{O}_{3}$ & & $\mathrm{O}_{4}$ \\
\hline
\end{tabular}
diberi pretest untuk mengetahui keadaan awal peserta didik dan diberi posttest untuk mengetahui keadaan akhir setelah diberi perlakuan pada kelas eksperimen mengunakan model pembelajaran berbasis proyek (project based learning) dan kelompok kontrol diberikan perlakuan menggunakan model pembelajaran konvensional (Sugiyono, 2014).

Penelitian dilaksanakan di MTs. Swasta Matla'ul Anwar Gisting. Variabel dalam penelitian ini terdiri dari dua jenis yaitu Variabel bebas (X) dan variabel (Y). Variabel bebas berupa model pembelajaran proyek (Project-Based Learning) yang menjadi variabel terikat adalah Keterampilan Proses Sains (Y).

\section{Populasi, Sampel dan Teknik Pengambilan Sampel}

1. Populasi

Populasi pada penelitian ini adalah seluruh peserta didik kelas VIII MTs. Swasta Matla'ul Anwar Gisting, populasi tersebut kelas VIII (A, B, dan C).

\section{Sampel}

Sampel yang akan diambil dalam penelitian ini adalah dua kelas, yaitu kelas VIII A dan kelas VIII C MTs. Swasta Matla'ul Anwar Gisting.

3. Teknik Pengambilan Sampel
Teknik Pengambilan Sampel yang digunakan pada penelitian ini adalah Teknik Pengambilan simple random sampling.

\section{Teknik Pengumpulan Data}

Untuk memperoleh data dalam penelitian, peneliti menggunakan beberapa metode pengumpulan data, di antaranya adalah sebagai berikut:

1. Tes keterampilan proses sains

2. Angket

3. Observasi

4. Dokumentasi

\section{Uji coba instrumen}

\section{Uji Validitas}

Untuk mengetahui validitas butir soal digunakan rumus :

$r_{x y}=\frac{N \sum X Y-\left(\sum X\right)\left(\sum Y\right)}{\sqrt{\left.\left.\left[N \sum X^{2}-\left(\sum X\right)^{2}\right)\right]\left[N \sum Y^{2}-\left(\sum Y\right)^{2}\right)\right]}}$

Keterangan :

$r_{x y}=$ Koefisien korelasi antara variabel $\mathrm{x}$ dan variabel $\mathrm{y}$.

$\mathrm{X}=$ Koefisien butir soal.

$\mathrm{Y}=$ Skor total.

$\mathrm{N}$ = banyaknya responden.

Butir soal dikatakan valid apabila $r_{x y}>r_{\text {tabel. }}$. Jika $r_{x y} \leq r_{\text {tabel }}$ maka soal dikatakan tidak valid (Sudijono, 2011).

2. Uji Reliabilitas

Perhitungan uji reliabilitas dengan menggunakan rumus Alpha:

$r_{11}=\left(\frac{n}{n-1}\right)\left\{\frac{s^{2}-\Sigma_{p q}}{s^{2}}\right\}$

Dengan :

$\begin{array}{ll}r_{11} & \begin{array}{l}\text { : Reliabilitas tes secara } \\ \text { keseluruhan }\end{array} \\ p & : \text { Proporsi subjek yang } \\ & \text { menjawab item } \\ & \text { dengan benar } \\ q & \text { : Proporsi subjek yang } \\ & \text { menjawab item dengan } \\ & \text { salah (q= 1-p) } \\ n & \text { : Banyaknya item. } \\ \sum_{p q} & \text { : Hasil jumlah perkalian } \\ & \text { antara p dan q. }\end{array}$




$$
S^{2}
$$

: Standar deviasi dari tes (standar deviasi adalah akar varians).

Koefisien reliabilitas yang diperoleh diinterpretasikan terhadap koefisien reliabilitas tes yang pada umumnya digunakan patokan sebagai berikut:

Tabel 2. Kriteria Indeks Reliabilitas Soal

\begin{tabular}{cc} 
Indeks Reliabilitas & Kriteria Reabilitas \\
\hline IR $\leq 0,20$ & Sangat rendah \\
$0,20>$ IR $\leq 0,40$ & Rendah \\
$0,40>$ IR $\leq 0,60$ & Cukup \\
$0,60>$ IR $\leq 0,80$ & Tinggi \\
$0,80>$ IR $\leq 1,00$ & Sangat tinggi \\
\hline
\end{tabular}

(Arikunto, 2012)

3. Uji Tingkat Kesukaran

Menghitung tingkat kesukaran butir tes digunakan rumus :

$$
\mathrm{P}=\frac{B}{J S}
$$

Keterangan:

$\mathrm{P} \quad=$ Indeks kesukaran

B =Banyaknya siswa yang jawab soal itu dengan betul.

JS = Jumlah seluruh peserta didik tes.

Kriteria indeks kesukaran soal adalah sebagai berikut:

Tabel 3.Interprestasi Tingkat Kesukaran

\begin{tabular}{cc}
\hline Nilai $\mathbf{p}$ & Katagori \\
\hline $\mathrm{P}<0,30$ & Sukar \\
$0,3 \leq \mathrm{p} \leq 0,7$ & Sedang \\
$\mathrm{P}>0,7$ & Mudah \\
\hline
\end{tabular}

(Arikunto, 2010)

4. Uji Daya Beda

Indeks daya pembeda dapat dicari dengan menggunakan rumus sebagai berikut :

$$
\mathrm{D} \quad=\frac{B A}{J A}-\frac{B B}{J B}=P_{A}-P_{B}
$$

Keterangan:

$\mathrm{D}=$ Daya pembeda .

$\mathrm{JA}=$ Banyaknya peserta kelompok atas.

$\mathrm{JB}=$ Banyaknya peserta kelompok bawah.

$\mathrm{BA}=$ Proporsi peserta kelompok atas yang menjawab benar.
$\mathrm{BB}=$ Proporsi peserta kelompok atas yang menjawab salah.

Selanjutnya hasil akhir dari perhitungan daya beda didefinisikan dengan indeks daya pembeda sebagai berikut :

Tabel 4.Klasifikasi Daya Beda

\begin{tabular}{cc}
\hline DP & Kriteria \\
\hline $0,70>\mathrm{DP} \leq 1,00$ & Sangat Baik \\
$0,40>\mathrm{DP} \leq 0,70$ & Baik \\
$0,20>\mathrm{DP} \leq 0,40$ & Sedang \\
$\mathrm{DP} \leq 20$ & Lemah/Jelek \\
\hline (Suharsimi Arikunto, 2009, 213-218)
\end{tabular}

\section{Efektivitas Pengecoh}

Efektivitas Pengecoh dihitung dengan rumus sebagai berikut:

$$
\mathrm{IP}=\frac{P}{(N-B) /(N-1) \times 100 \% 6}
$$

Keterangan :

IP $=$ indeks pengecoh

$\mathrm{P}=$ jumlah peserta didik yang memilih pengecoh

$\mathrm{N}=$ jumlah peserta didik yang ikut tes

$\mathrm{B}=$ jumlah peserta didik yang menjawab benar pada setiap soal

$\mathrm{n}$ = jumlah alternative jawaban

1 = bilangan tetap. (Arifin, 2009)

\section{Pengambilan Kesimpulan Butir Soal}

Berdasarkan hasil perhitungan dan analisis uji validitas, tingkat kesukaran, daya beda dan uji reliabilitas butir soal keterampilan proses sains dan evektifitas pengecoh. Dalam penelitian ini soal yang digunakan sebagai tes keterampilan proses sains fisika di Kelas Eksperimen 1 dan Kelas kontrol adalah soal-soal yang memenuhi kriteria. Berdasarkan hasil perhitungan, diketahui bahwa dari 24 soal pilihan ganda terdapat 20 soal yang dinyatakan diterima dan 4 soal yang dinyatakan ditolak. Selanjutnya, soal yang dinyatakan diterima digunakan sebagai instrumen tes berjumlah 20 soal prettest 
dan posttes yang digunakan dalam penelitian ini.

\section{Teknik Analisis Data}

Setelah data terkumpul, data di analisis dengan menggunakan langkah-langkah sebagai berikut:

\section{Uji Normalitas}

Uji normalitas data dilakukan untuk mengetahui apakah data yang diperoleh dari populasi yang berdistribusi normal atau tidak dengan menggunakan rumus lilliefors. Dengan langkah- langkah sebagai berikut:

a) Hipotesis

$H_{0}$ : Sampel berasal dari populasi yang berdistribusi normal $H_{1}$ : Sampel tidak berasal dari populasi yang berdistribusi normal

b) Taraf Signifikan $(\alpha)=0,05$

c) Statistik uji

d) Keputusan uji $H_{0}$ ditolak jika $L_{\text {hitung }}$ terletak didaerah kritis.

e) Kesimpulan

1. Sampel berasal dari populasi yang berdistribusi normal jika $H_{0}$ diterima

2. Sampel berasal dari populasi yang tidak berdistribusi normal jika $H_{0}$ ditolak.

Selanjutnya nilai $\mathrm{L}$ tersebut dibandingkan dengan $\mathrm{L}$ pada tabel dengan mengambil nilai $\alpha=0,05$. Jika $L$ hitung lebih kecil dari $\mathrm{L}$ tabel maka sampel berasal dari populasi yang normal (Budiyono, 2009).

\section{Uji Homogenitas}

Uji ini untuk mengetahui kesamaan antar dua keadaan atau proporsi. Uji homogenitas yang digunakan adalah uji homogenitas dua varians atau uji fisher.
Project Based Learning: Pengaruhnya.....

Dengan langkah-langkah sebagai berikut :
a. Rumuskan Hipotesis
b. Hipotesis
$\mathrm{H}_{0}$ : Kedua varians homogen
$\mathrm{H}_{\mathrm{a}}$ : Kedua varians tidak homogen
c. Taraf signifikan $(\alpha)=0,05$
d. Statistik Uji

$$
\mathrm{F}=\frac{\text { varians terbesar }}{\text { varians terkeil }}
$$

e. Daerah Kritis

$$
\mathrm{DK}:\left\{\mathrm{F} \mid \mathrm{F} \leq F_{2}^{1} \frac{1}{2} \alpha_{\left(n_{1}-1, m_{2-1}\right)}\right\}
$$

f.Kesimpulan

$\mathrm{H}_{0}$ diterima jika $\mathrm{L}_{\text {hitung }} \leq \mathrm{L}_{\text {tabel }}$ maka kedua kelas homogen.

(Sundayana, 2015)

\section{Uji Hipotesis}

Uji hipotesis ini dilakukan dengan menggunakan rumus uji $t$ sebagai berikut:

$$
\mathrm{t}=\frac{\bar{X}_{1}-\bar{X}_{2}}{\sqrt{\frac{\left(n_{1}-1\right) s_{1}^{2}+\left(n_{2}-1\right) s_{2}^{2}}{n_{1}+n_{2}-2 x}\left(\frac{1}{n_{1}}\right)+\left(\frac{1}{n_{2}}\right)}}
$$

Keterangan :

$\bar{X}_{1}$ : rata-rata kemampuan kelas eksperimen.

$\bar{X}_{2}$ : rata-rata kemampuan kelas kontrol.

$n_{1} \quad$ : banyaknya peserta didik kelas eksperimen.

$n_{2} \quad$ : banyaknya peserta didik kelas kontrol.

$S_{1}^{2} \quad$ : varians data kelompok eksperimen.

$S_{2}^{2} \quad$ : varians data kelompok kontrol.

$$
H_{0}: \mu_{1} \leq \mu_{2} \text { (Apabila hasil tes }
$$
keterampilan proses sains peserta didik kelas eksperimen lebih kecil atau sama dengan dari hasil keterampilan proses sain kelas kontrol maka hipotesis ditolak).

$$
\begin{array}{r}
H_{1}: \mu_{1}>\mu_{2} \text { (Apabila hasil tes } \\
\text { keterampilan proses sains }
\end{array}
$$


peserta didik kelas eksperimen lebih besar atau tidak sama dengan dari hasil keterampilan proses sain kelas kontrol Kesimpulan: maka hipotesis diterima).

Jika $t_{\text {hitung }}<\mathrm{t}_{\text {tabel }}$ maka $\mathrm{H}_{0}$ diterima, dan jika thitung $\geq \mathrm{t}_{\text {tabel }} \mathrm{H}_{0}$ ditolak.

(Sugiyono, 2015)

\section{Teknik Analisis Keterampilan proses} Sains

Tes keterampilan proses sains digunakan untuk mengetahui gambaran, keterampilan proses sains peserta didik. Tahapan analisisnya sebagai berikut:

a. Menjumlahkan indikator yang teramati.

b. Menghitung presentase aspek keterampilan proses sains peserta didik dalam kelompok, dengan menggunakan rumus:

$\%$ keterampilan proses sains $=\frac{\text { skor yang diperoleh }}{\text { skor yang }}$

Data yang diperoleh kemudian diinterpretaikan ke dalam Kriteria nilai sebagai berikut:

Tabel 5. Kriteria Interpretasi Skor

\begin{tabular}{|c|c|}
\hline Presentase & Keterangan \\
\hline $80>P \leq 100$ & Sangat Baik \\
\hline $60>\mathrm{P} \leq 80$ & Baik \\
\hline $40>\mathrm{P} \leq 60$ & Cukup \\
\hline $20 \leq \mathrm{P} \leq 40$ & Kurang \\
\hline$<20$ & Sangat Kurang \\
\hline
\end{tabular}

\section{HASIL DAN PEMBAHASAN}

Dalam penelitian ini, peneliti menggunakan dua kelas sebagai sampel yaitu Kelas VIII C sebagai Kelas Eksperimen yang menggunakan model project based learning ( $\mathrm{PjBL})$ dan kelas VIII A sebagai kelas kontrol.
Peneitian ini bertujuan untuk mengetahui perbedaan keterampilan proses sains peserta didik dalam pembelajaran konsep gerak dengan model pembelajaran berbasis proyek dengan metode konvensional. Tes keterampilan proses yang diukur pada penelitian ini adalah mengamati, mengelompokkan, menerapkan konsep, memprediksi, menafsirkan, merancang percobaan, menggunakan alat dan bahan, mengajukan pertannyaan, komunikasi, dan hipotesis. Tes keterampilan proses sains yang dilakukan berupa tes dan nontes. Data-data yang dideskripsikan merupakan data hasil lembar observasi keterampilan proses sains dan tes hasil belajar berupa pilihan ganda sebanyak 20 soal.

Berdasarkan penelitian yang telah dilakukan didapatkan hasil sebagai berikut:

a. Hasil Lembar Observasi Keterampilan Proses Sains Kelas Eksperimen

Berdasarkan hasil analisis pada lembar obsevasi keterampialn proses sains bahwa dari semua aspek keterampilan proses sains yang dimiliki peserta didik kelas eksperimen meniliki rata-rata persentasi sebesar 79,37\%, dan aspek mengamati adalah aspek yang tertinggi yang dicapai oleh peserta didik yaitu mendapat persentasi rata-rata $85,41 \%$. Aspek yang rendah yaitu aspek menggunakan alat dan bahan dan hipotesis yaitu sebesar $75 \%$.

b. Hasil Tes Keterampilan Proses Sains Kelas Kontrol dan Kelas Eksperimen

Berdasarkan hasil perhitungan menunjukkan bahwa terdapat perbedaan yang cukup signifikan dari hasil posttes kelas kontrol dan kelas eksperimen. Pada kelas kontrol, nilai rata-rata persentasi peserta didik keterampilan proses sains yaitu $54,46 \%$. Sedangkan kelas eksperimen rata-rata persentasinya sebesar $70,47 \%$. Aspek tertinggi pada kelas kontrol ada pada aspek mengamati dengan niali 
$73,21 \%$ untuk kategori cukup. Dan pada kelas eksperimen, nilai persentasi tertinggi ada pada aspek menerapkan konsep dengan niali $78,13 \%$ untuk kategori baik. Sedangkan niali persentasi terkecil di kelas kontrol ada pada aspek hipotesis dengan nilai $44,64 \%$ untuk kategori kurang. Dan pada kelas eksperimen, nilai persentasi terendah ada pada aspek menafsirkan dan menggunakan alat dan bahan dengan nilai $65,63 \%$ untuk kategori cukup.

Untuk hasil uji normalitas posttest pada kelas kontrol, diperoleh nilai $\mathrm{L}_{\text {hitung }}=0,114$ dan nilai $\mathrm{L}_{\text {tabel }}=0,167$ dan hasil uji normalitas postest pada kelas eksperimen nilai $L_{\text {hitung }}=0,177$ dan untuk nilai $L_{\text {tabel }}=0,185$. Dengan demikian nilai hasil prettest kedua kelas kontrol dan kelas eksperimen berdistribusi secara normal. Nilai tersebut menunjukkan bahwa Lhitung $_{\text {< }}$ $\mathrm{L}_{\text {tabel. }}$ sedangkan untuk hasil homogenitas postest kelas kontrol dan kelas eksperimen menggunakan uji fisher, yaitu untuk $\mathrm{F}_{\text {hitung }}$ tes akhir 0,58 dengan $F_{\text {tabel }} 4,006$ pada taraf nyata 0,05 , maka $F_{\text {hitung }}<F_{\text {tabel }}=0,58<4,006$ Hal ini menujukan tidak terdapat perbedaan yang signifikan berarti data tersebut homogen atau sama. Karena kedua kelompok tersebut berdistribusi normal dan homogen, maka langkah selanjutnya yaitu menguji hipotesis dengan menggunakan uji t. Dari hasil uji t nilai tes akhir menunjukkan bahwa $t_{\text {hitung }}>t_{\text {tabel }}$ yaitu $5>2$ maka $\mathrm{H}_{1}$ diterima

Dengan demikian terdapat perbedaan yang cukup signifikan antara hasil keterampilan proses sains peserta didik dengan menggunakan model pembelajaran berbasis proyek dengan menggunakan konvensional.

pembelajaran

Dari hasil perhitungan diperoleh kesimpulan bahwa nilai persentasi postest kelas eksperimen menggunakan model project based learning (PjBL) lebih tinggi dari kelas kontrol yang menggunakan metode konvensional. Dan pada lembar observasi keterampilan proses sains dari semua aspek yang dimiliki kelas eksperimen bahwa keterampilan proses sains dikategorikan baik.

Model project based learning (PjBL) membantu peserta didik terlibat secara aktif dalam proses pembelajaran secara langsung dimana peserta didik yang lebih aktif dan mencari tahu sendiri solusi dari permaslahan yang telah diberikan oleh guru serta peserta didik berhadapan nyata dengan objekobjek yang dapat menyelesaikan permasalahannya dan mencari tahu kebenaran konsep yang sedang dipelajarinya, sehingga pesera didik belajara secara mandiri dan peserta didik dapat mengembangkan aspek keterampilan proses sains. Sedangkan pembelajarn dengan menggunakan pendekatan konsep ada kecenderungan peserta didik dituntut mengingat konsep bukan diajak melakukan kegiatan untuk mendapatkan dari mana konsep itu diperoleh, sehingga pada akhirnya akan berpengaruh pada lama tidaknya penyimpanan pengetahuan di dalam memori peserta didik. Karena itu peserta didik tidak dapat mengembangkan keterampilan proses sains yang ada pada diri peserta didik itu sendiri.

\section{KESIMPULAN DAN SARAN Kesimpulan}

Berdasarkan hasil penelitian dapat disimpulkan bahwa model project based learning (PjBL) memiliki pengaruh terhadap keterampilan proses sains peserta didik pada materi gerak lurus. Hasil uji-t postest menunjukkan bahwa thitung $=10,17$ lebih besar $\mathrm{t}_{\text {tabel }(0,05)}=2$, sehingga $\mathrm{t}_{\text {hitung }}>$ $t_{\text {tabel }}$. Jadi dapat disimpulkan bahwa $\mathrm{H}_{1}$ diterima, artinya terdapat pengaruh keterampilan proses sains peserta didik 
dengan model pembelajaran berbasis proyek. Data postest kelas eksperimen menunjukkan perbedaan yang cukup signifikan rata-rata persentasi nilai keterampilan proses sains kelas eksperimen mendapat persentasi sebesar 69,84\% sedangkan kelas kontrol mendapat rata-rata persentasi $39,64 \%$. Adapun pada lembar observasi keterampilan proses sains tertinggi pada kelas eksperimen yaitu mengamati $85,41 \%$ dan keterampilan proses sains yang terendah adalah hipotesis dan menggunakan alat dan bahan yaitu sebesar $75 \%$.

\section{Saran}

Berdasarkan hasil penelitian, maka dapat disarankan kepada pendidik atau calon pendidik untuk melakukan alternatif pembelajaran, salah satunya dengan menggunakan model project based learning $(\mathrm{PjBL})$ berpengaruh terhadap kemampuan berpikir kritis peserta didik. Dari hasil penelitian ini juga dapat diadakan penelitian lanjutan tentang pembelajaran dengan model project based learning $(\mathrm{PjBL})$ konsep atau topik yang berbeda.

\section{DAFTAR PUSTAKA}

Al-Tabany, T. I. B. (2014). Mendesain Model Pembelajaran Inovatif, Progresif, dan Konstektual. Jakarta: Prenadamedia.

Aqib, Z. (2014). Model-Model,Media Dan Strategi Pembelajaran Kontekstual (Inovatif). Bandung: CV Yrama Widya.

Arifin, Z. (2009). Evaluasi Pembelajaran. Bandung: Rosda Karya.

Arikunto, S. (2010). Prosedur Penelitian Suatu Pendekatan Praktik. Jakarta: Rineka Cipta.

Arikunto, S. (2012). Dasar-Dasar Evaluasi Pendidikan. Jakarta: Bumi Aksara.

Avianti, R., \& Yonatha, B. (2015). Keterampilan Proses Sains Siswa
Melalui Peneapan Model

Pembelajaran Koopeatif Materi Asam Basa Kelas XI SMAN 8 Surabaya. UNESA Journal of Chemical Education, 4(2), 224-231.

Budiyono. (2009). Statistik untuk Penelitian. Surakarta: UNS Press.

Departemen Agama RI. (2010). AlHikmah Al-Qur'an danTerjemahannya. Bandung: Diponegoro.

Dimayati, \& Mujiono. (2006). Belajar dan Pembelajaran. Jakarta: Rineka Cipta. Hasbullah. (2013). Dasar-Dasar Ilmu Pendidikan (Edisi Revisi). Jakarta: PT Raja Grafindo Persada.

Komikesari, H. (2016). Peningkatan Keterampilan Proses Sains dan Hasil Belajar Fisika Siswa pada Model Pembelajaran Kooperatif Tipe Student Team Achievement Division. Tadris: Jurnal Keguruan Dan Ilmu Tarbiyah, 1(1), 15-22.

Kurnia, B., \& Bahtiar. (2015). Pengaruh Strategi Think-Talk-Write (TTW) Berbasis Kontekstual terhadap Keterampilan Proses Sains Siswa Kelas VII MTs NW Wanasaba Lombok Timur Tahun Pelajaran 2014/2015. Biota: Jurnal Biologi Dan Penidikan Biologi, 8(1).

Sani, A. R. (2014). Pembelajaran Saintifik Untuk Implementasi Kurikulum 2013. Jakarta: PT.Bumi Aksara.

Sudijono, A. (2011). Pengantar Evaluasi Pendidikan. Jakarta: Rajawali Pers.

Sugiyono. (2014). Metode Penelitian Pendidikan; Pendekatan Kuantitatif, Kualitatif, dan $R \& D$. Bandung: Alfabeta.

Sugiyono. (2015). Metode Penelitian Pendidikan Pendekatan Kuantitatif, Kualitatif, dan $R$ \& D. Bandung: Alfabetha.

Sundayana, R. (2015). Statistikka Penelitian Pendidikan. Bandung: Alfabeta.

Trianto. (2012). Model Pembelajaran 
Terpadu. Jakarta: Bumi Aksara.

Widayanto. (2009). Pengembangan

Keterampilan Proses dan Pemahaman

Siswa Kelas X Melalui KIT Optik.

Jurnal Pendidikan Fisika Indonesia, 5(1), 1-7.

Yuberti, Y. (2015). Online Group

Discussion pada Mata Kuliah

Teknologi Pembelajaran Fisika.

Jurnal Ilmiah Pendidikan Fisika Al-

Biruni, 4(2). 